\section{Science for Britain set to back a "free world perspective"}

\section{London}

SIR Ian MacGregor, former chairman of Britain's National Coal Board, last week announced the formation of a new pressure group, Science for Britain. The new group, of which MacGregor is president, has the support of the Watt committee, which represents 62 institutions with an interest in energy, and the British Science and Technology Trust, a charity aimed at encouraging more young people to embark on careers in science.

Another backer is the recently formed Advanced Energy Research Institute (AERI), a private organization founded by MacGregor and Canadian businessmen Leonard Holihan, who intends to identify and secure financial backing for potentially exploitable ideas and inventions "from a free world perspective".

According to the leaflet announcing Science for Britain, innovators and their concepts frequently leave Britain, impoverishing its ability to compete internationally "to protect and promote our freedom". The group also calls for encouragement of international participation in "the strategic vastness of space development". One of its stated aims is to "emphasize Britain's role in spearheading technological advancement in the western democracies and to promote awareness of the direct link between scientific progress, jobs, prosperity, peace and freedom". The leaflet invites voluntary donations to the campaign.

AERI is currently devoting most of its attention to high-temperature superconductivity. Indeed, for its launch, at the British Science Museum on 15 July, Holihan attracted the interest of researchers and the media when he promised to announce a significant breakthrough in superconductivity. The 'high-current density' ceramic cylinder he displayed, manufactured by a small four-man company AERI has taken under its wing, failed to impress the academics.

Holihan and MacGregor met a few years ago and discovered they shared an interest in "catalysing future technological developments". They formed, in 1983, the Aeronautical Research Institute (ARI), which was particularly interested in "small vertifical take-off and landing conceptions" (more popularly known as flying saucers). AERI is a successor to ARI, with wider aims.

According to Holihan, AERI identifies potentially exciting projects through its network of contacts, and then tries to interest potential backers. It is looking to accelerate technological developments from a "free-world perspective". To explain that term, Holihan says: "There is the free world and there is the Soviet bloc. Science does not happen in a vacuum devoid from politics or totalitarianism. We should all be tuned in to what the Soviets are working on as far as technology to avoid a technological run-in. The free world has to be astute as to what the strategies and priorities are in regards to scientific technology to protect and preserve our freedom. It is not just science

In 1981, Holihan and two Conservative politicians set up an organization called 'Coalition for Peace through Security', a right-wing pressure group opposed to the growing support for the unilateral disarmament lobby in Britain.

Shortly afterwards he directed a 'private think tank on strategic affairs'

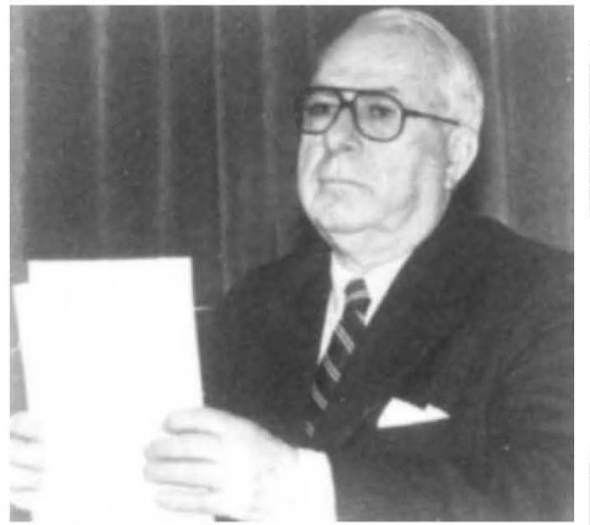

MacGregor announces a new pressure group avowed to "emphasize Britain's role in spearheading technological advancement".

AERI is in the process of establishing a consultative council. The only name Holihan is prepared to release at this stage is that of Sir Kenneth Corfield, director of Midland Bank, Britoil and Octagon Group. Holihan says "a few more" people have agreed to join the consultative council, but their names will not be announced until the full establishment of 12 has been reached.

Holihan says AERI is looking seriously at "a dozen or so" projects, and although no funding has yet been secured, severa potential backers, whom Holihan declines to name, are "interested". He says: "Sir Ian and I are passionately interested in science and technology and its practical applications to help people. It's good for business and it's good for strategic reasons." Asked if AERI is interested in military applications of technology, Holihan said: "We are not particularly concerned with weaponry but obviously anything has some applications towards that." Holihan says that AERI is "absolutely unpolitical. I am not a political person. This work is trans-political".

Simon Hadlington for science's sake".
French suspect information on radiation levels

\section{Paris}

ACCORDING to a survey carried out for the French Industry ministry, only 35 per cent of those interviewed believed the government would be ready to protect the safety of the population in the event of a major nuclear accident, such as occurred at Chernobyl last year.

Almost half (49 per cent) of the sample were "very" or "quite" worried about the likelihood of such an accident in France. This represents a marked change in the climate of public opinion in France since 1985 , when only 33 per cent of those questioned said they were concerned.

For France, which is second only to the United States in its investment in nuclear energy - with few naturally occurring alternative energy sources - public confidence has been a significant factor enabling successive governments to continue to build reactors when all of France's European neighbours slowed or halted construction because of public pressure.

All official statements about radiation levels are routed through the government 'mouthpiece', the SCPRI (Service Central de Protection Contre les Radiations Ionisantes). Following the Chernobyl accident, it was the SCPRI who initially denied that the radioactive cloud had passed over France and, subsequently, published local measurements of radiation levels in soil which were 80 per cent lower than those recorded by Electricité de France, who operate all nuclear reactors in France.

Doubts over the accuracy of figures released by SCPRI have led to the creation of an independent body, CRIIRAD, which periodically monitors levels of radiation in foodstuffs. With the arrival of autumn, when French families traditionally go mushrooming, CRIIRAD has recorded high levels of caesium 137 and caesium 134 (up to 24,000 becquerels per kilogram) in certain edible fungi collected in the east of France. But as records of radiation levels in these fungi before the Chernobyl accident have not been kept, it is impossible to interpret the new measurements.

Another group, composed of nuclear scientists and calling itself the Groupement de Scientifiques pour L'information sur L'energie Nucléaire (GSIEN), has been set up to inform the public on nuclear energy problems. One of its aims is to lobby the International Commission on Radiological Protection for a lowering of recommended 'safe' dose levels of radiation to take account of recent research (see Nature 329, 96; 1987).
Peter Coles 